\title{
COUNTER-RADICALIZATION IN EARLY CHILDHOOD THROUGH EFFECTIVE COMMUNICATION BETWEEN EDUCATION STAKEHOLDERS IN BIMA
}

\author{
Akhmad Asyari'; Kadri ${ }^{2}$ \\ 1,2Universitas Islam Negeri Mataram, NTB, Indonesia \\ 1 asyarismart@yahoo.com; ${ }^{2}$ kadri@uinmataram.ac.id
}

\begin{abstract}
This research reveals the reality of early childhood education in Bima, West Nusa Tenggara as an area prone to radicalism, especially to see the policies and implementation of the counter-radicalization agenda in early childhood, including portraits of communication between stakeholders in tackling the spread of radicalism in Bima. This qualitative research took place from August 2018 to July 2019. The results showed that early childhood education institutions in Bima had not maximally used counter-radicalization content as teaching material even though they lived in the areas prone to radicalism. Communication between education stakeholders such as parents, educators, and the government has also not been effective. This is reflected in the lack of collective counter-radicalization action, so that preventive steps to counter radicalism seem minimal. The lack of coordination and communication for education against radicalization counter-narratives at the early childhood level has made hopes for an inclusive generation in Bima to be born.
\end{abstract}

Keywords: Communication, education, counter-radicalization, Early Childhood

\section{INTRODUCTION}

Children are now at the forefront of war, conflict and terrorism as a consequence of a paradigm shift in the growing nature of terrorism cases. They are as vulnerable as adults to the traumatic effects of violence and mass violence (Williams, 2007: 263). Furthermore, the involvement of children as terrorists is not new cases but it happens continuously, as what happened in the suicide bombing in Surabaya City in May 2018 made everyone dumbfounded, because the incident involved a 9 year old child after being invited by someone. This incident indicates that it is important to pay attention to the counter-narrative of radicalization to the family or household 
Asyari, A., \& Kadri (2020). COUNTER-RADICALIZATION IN EARLY CHILDHOOD THROUGH EFFECTIVE COMMUNICATION BETWEEN EDUCATION STAKEHOLDERS IN BIMA. Jurnal Tatsqif, 18 (1), 1-21. https://doi.org/10.20414/itq.v17i2.2262

environment because it is a vulnerable place for the cultivation of radical values if parents as the main educators in the family have a strong will to instill radical values in their children.

The incident in Surabaya in 2018 is an important lesson for us that radical values education has entered the family room. Dita Supriyanto's family has shocked the whole world when a family carried out a bombing at three churches in Surabaya, May 13, 2018. Dita Supriyanto who lives in Wonorejo Asri, Rungkut District, Surabaya City invited his wife, Puji Kuswati, and four children, two boys respectively Yusuf Fadil (18) and Firman Halim (16), and two other daughters Fadhila Sari (12) and Pamela Riskita who are 9 years old (kompas.com, 13/5 / 2018).

The involvement of children in the violent and radical acts as described above requires efforts from an early age to instill the values of religious inclusiveness and moderation in early childhood, as suggested by Hilmi (2015) regarding the importance of a de-radicalization policy and program specifically placing children and young people as the main target. In this context, the importance of communication collaboration between all parties (especially parents and teachers in educational institutions) in carrying out inclusive and counter-radicalization education in children from an early age, especially in areas that have levels of activity and violent actions from radical groups that are more intense in compare it with other regions, or areas that are prone to radicalism.

Bima City and Bima districts (called Bima) are known as areas with high levels of violence and radicalism compared to other areas in West Nusa Tenggara. The research results of the Nusa tenggara Center (2017) showed that the escalation of conflict in Bima district (in the period 2015 - May 2017) occupies the highest position compared to other districts and cities in West Nusa Tenggar Province (see figure 1). 
Asyari, A., \& Kadri (2020). COUNTER-RADICALIZATION IN EARLY CHILDHOOD THROUGH EFFECTIVE COMMUNICATION BETWEEN EDUCATION STAKEHOLDERS IN BIMA. Jurnal Tatsqif, 18 (1), 1-21. https://doi.org/10.20414/itq.v17i2.2262

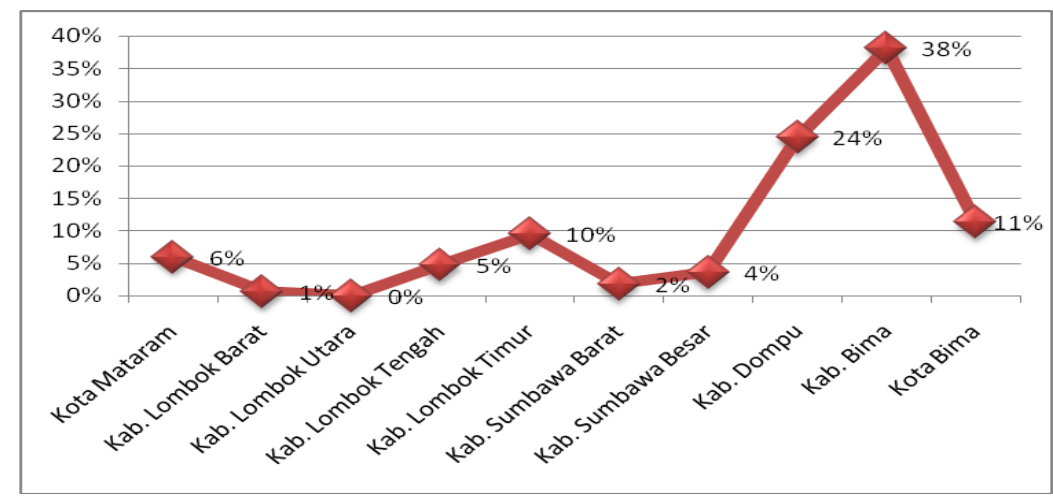

Figure 1. Escalation of Conflict in NTB 2015 - May 2017

Source: Nusatenggara Center, 2017

Figure 1 shows explicitly the number of conflicts that occurred in Bima district $(38 \%)$ more than the conflicts that occurred in other regions or districts and cities in NTB. The data reinforces the dominance of the conflict followed by violence that occurred in Bima so that when there are people who identify the area as a conflict area or zone and violence is not completely wrong. Some of the violence that took place in Bima was also perpetrated by radical elements or groups with an exclusive religious understanding. Several cases of radical and terrorist acts that have occurred in Bima, for example the explosion of a bomb at the Umar Bin Khatab Islamic boarding school, Sanolo Village, Bima Regency in 2011. In 2014 there was also a shooting which killed the Head of the Ambalawi Police, Bima district, which was later discovered by the main actor being Syarif, a member of the terrorist Mujahidin Indonesia Timur (MIT). In October 2017 there was also a shooting of a terrorist group by the police in the Ambalawi sub-district, Bima regency (jawapos.com, 30/10/2017).

The data and facts above show that the Bima area needs serious treatment in tackling the widespread violence and radicalism so that these actions do not affect the mental and character of the children in Bima. It is in this context that it is important to carry out counter-radicalization efforts or programs on a massive and planned basis from an early age by involving parents and teacher in educational institutions. Children in general and early 
Asyari, A., \& Kadri (2020). COUNTER-RADICALIZATION IN EARLY CHILDHOOD THROUGH EFFECTIVE COMMUNICATION BETWEEN EDUCATION STAKEHOLDERS IN BIMA. Jurnal Tatsqif, 18 (1), 1-21. https://doi.org/10.20414/itq.v17i2.2262

childhood in particular are strategic segments to be targeted by counterradicalization programs if they want to instill inclusive values from the start, especially if this effort is carried out by collaborating with local wisdom values.

The Early childhood is the right time to install inclusive values so that children will grow and develop as a generation who are happy with being together, maintaining or caring for good values and peace. One aspect that can be addressed at the early childhood education level is to strengthen collaboration between parents and teacher in educational institutions by giving priority to the counter-radicalization content in the educational process. This effort is at the same time used as a counter movement against efforts to instill radical values at an early age by radicalism groups and communities.

When an Early childhood are considered vulnerable to radicalism and Bima is an area prone to radicalism, then what is the condition of the content taught in early childhood education institutions in that area, and how do parents instill the value of inclusiveness and counter-radicalization content in their children. Another question, how is the portrait of communication between education stakeholders - such as the parents, teacher, community, and local government - in anticipating the spread of radicalism in Bima. These are the questions that are answered through this research.

\section{THEORETICAL FRAMEWORK}

It can be understood that terrorism committed by jihadist groups in Indonesia, such as Jamaah Islamiyah (JI) and the Islamic State of Indonesia (NII), are a form of religious activity (amaliyah) because, unlike ordinary crimes, they are based on religious values. Thus charismatic leaders such as Oman Abdurrahman never admit the actions carried out by activists are considered as acts of terrorism or crimes (Sukabdi, 2015: 6). 
Asyari, A., \& Kadri (2020). COUNTER-RADICALIZATION IN EARLY CHILDHOOD THROUGH EFFECTIVE COMMUNICATION BETWEEN EDUCATION STAKEHOLDERS IN BIMA. Jurnal Tatsqif, 18 (1), 1-21. https://doi.org/10.20414/itq.v17i2.2262

The radicalism that has developed in Indonesia (including in Bima) should not only be resisted repressively when they commit acts of violence, but must also exist or spread it by engaging in counter movements or commonly known as de-radicalization movements. De-radicalization is a necessity (see Zuhdi, 2015: 28) and an enlightening solution to tackling the terrorist threat. Using a religious approach is a dangerous form of deradicalization that uses guns and bullets which will create revenge and wider acts of terror.

De-radicalization and counter-radicalization efforts as a way to fight radical ideologies and groups are termed by Milla et al (2020) as an effort to fight terrorists and radicals without weapons, especially by giving priority softer approaches such as building good social communication and making family communication effective. Educational institutions are important institutions that can be maximally utilized to build a line of resistance against radicalism. Utilizing educational institutions are by improving the Islamic Religious Education curriculum as proposed by Saifuddin (2016) with the Problem Based Learning approach.

Besides the de-radicalization program in Indonesia, there is also an emphasis on providing counseling programs for detained terrorists. This interactive media plays a role as a process to change their perceptions of terrorism and claim that these actions could have a negative impact on national security and threaten the lives of innocent people, especially children, women and the elderly (Rosili, 2016: 156).

In a more concrete form, de-radicalization and counter-radicalization efforts can use several options. Rokhmad (2012) offers three types of deradicalization that can be implemented in overcoming radicalism are preventive de-radicalization, preservative de-radicalization of moderate Islam, and curative de-radicalization. Collaborative de-radicalization education between parents and educators in early childhood as found in this research is a form of preventive de-radicalization against radicalism. 
Asyari, A., \& Kadri (2020). COUNTER-RADICALIZATION IN EARLY CHILDHOOD THROUGH EFFECTIVE COMMUNICATION BETWEEN EDUCATION STAKEHOLDERS IN BIMA. Jurnal Tatsqif, 18 (1), 1-21. https://doi.org/10.20414/itq.v17i2.2262

Education is a solution as well as a tool for building a nonviolent generation. The nonviolent education ideally starts at an early childhood and continues through secondary education. A tiered nonviolent education scheme like this requires multi-stakeholder involvement in it. Parents as supervisor in the household environment, the community as creators and carers of the social environment, and teachers who care for them while the child are in the school environment, and the legislature as regulators and the executive (government) as program implementers.

Nonviolence education at an early childhood is an urgent thing in the midst of the many temptations that teaches violence on children. Television, for example, has become a social educator that has the potential to brainwash the toddlers' characters and through the programs they serve. Shows in the child segment, such as cartoons or children's cinemas, are not yet completely sterile from slices of violence (verbal or non-verbal). In the midst of the happiness of our children while watching a funny scene from a cardboard film, without realizing it, at the same time there is an inculcation of violent values in them.

The cultivation theory (Susanto and Setiansah, 2010: 95) has taught us how television becomes a "poison" for children when it slowly but surely instills value to consumers (especially children). This means that if children watch programs containing violence, at that time the value of violence is internalized by them and will be practiced when they interact with their social environment. Or at least children become permissive with the violence.

It is in this context that the importance of counter-radicalization values is instilled in children at an early childhood by involving parents and teachers together. The counter-radicalization agenda that has been carried out by the government may need to be added by efforts to approach early childhood education institutions. Where the role of related agencies is to formulate a policy and curriculum that can be applied to minimize, even eliminate the potential for radical exposure in early childhood education. When an early 
Asyari, A., \& Kadri (2020). COUNTER-RADICALIZATION IN EARLY CHILDHOOD THROUGH EFFECTIVE COMMUNICATION BETWEEN EDUCATION STAKEHOLDERS IN BIMA. Jurnal Tatsqif, 18 (1), 1-21. https://doi.org/10.20414/itq.v17i2.2262

age a child has been implanted with the value of counter-radicalization or inclusiveness like this, then he will become a permanent memory in his brain, so that later as an adult he will have a strong understanding of the truth, and it is not easy to mislead other people who happen to have different views on several matters.

The communication between parents and teachers in instilling counterradicalization values in early childhood can be effective if there is a common orientation between them. This requirement is explicitly described in the ABX Newcomb Model (Mulyana, 2018: 143). The theory put forward by Theodore Newcomb assumes that communication between two people will work effectively if they are oriented or have the same interest and concern about something they are communicating.

When linked with the context of this research, it can be said that communication between parents and teachers in instilling counterradicalization values in early childhood will be successful if both are serious and caring and have a commitment to save children from radicalism and the violence.

Technically, their communication (parents and teachers in educational institutions) in instilling the value of counter-radicalization in early childhood can be implemented through the implementation of good communication strategies. Communication strategy is defined by Effendy (2017: 301) as a combination of communication planning and communication management. In a more operational context, a communication strategy is realized by paying attention to all elements of communication, as implicitly contained in the Lasswell model who says what in which channel to whom with what effect (Mulyana, 2018: 136).

By referring to the Lasswell model, the communication strategy is related to preparing communicators who convey the message (communication material) itself, the communication media, the communication target, and predicting or estimating the effect of the message conveyed. Therefore, the 
Asyari, A., \& Kadri (2020). COUNTER-RADICALIZATION IN EARLY CHILDHOOD THROUGH EFFECTIVE COMMUNICATION BETWEEN EDUCATION STAKEHOLDERS IN BIMA. Jurnal Tatsqif, 18 (1), 1-21. https://doi.org/10.20414/itq.v17i2.2262

communication strategy has a complex scope of study because it is related to the five elements of the communication with their respective levels of complexity and the relationship between one communication element and another, especially the interaction between one community and another in the context of interpersonal communication. . Therefore, collaborative communication between parents and teachers in instilling counterradicalization values in early childhood must be focus to the elements of the actors or communicators, messages, media, children's characters as communicants, and the effects that will be produced.

\section{METHOD}

This research uses a qualitative approach with a case study tradition. A research that uses a qualitative approach, according to Bodgan and Taylor (Moleong, 2020: 3), is a research procedure that produces descriptive data in the form of written or spoken words from people and observable behavior. This research is focused on exploring the realities of early childhood education in particular and children in general in Bima in relation with the efforts to instill counter-radicalization values of children. More specifically, this research is directed to look at collaborative communication between parents and teachers and other stakeholders in imparting counterradicalization values in early childhood.

This research took place from August 2018 to July 2019, taking locations in Bima District and Bima City, as regions or areas in the BNPT category as areas prone to terrorism. Data sourced from informants such as parents, early childhood education programs' teacher, the Education Office, community leaders, and other informants relevant to this research. To protect privacy information, their names in the research use initials. The data were collected by observing, documenting, and in-depth interviews. The data analysis was conducted qualitatively by following three stages of data analysis from Miles and Huberman (1992: 20), namely; data reduction, data 
Asyari, A., \& Kadri (2020). COUNTER-RADICALIZATION IN EARLY CHILDHOOD THROUGH EFFECTIVE COMMUNICATION BETWEEN EDUCATION STAKEHOLDERS IN BIMA. Jurnal Tatsqif, 18 (1), 1-21. https://doi.org/10.20414/itq.v17i2.2262

display, conclusion, and verification. All research results have been confirmed and received the informant's approval so that the level of accuracy of the data in this study can be accounted for. To ensure the validity of the data, the researcher did three things, namely; (a) extending the research period; (b) diligently making observations; (c) triangulation by comparing the results of interviews with observations; (d) conducting member checks, especially to reconfirm research results to informants; and (e) peer examination through discussion.

\section{FINGDING AND DISCUSSION}

\section{Early Childhood Education with Lack of Counter-Radicalization Content}

Many countries rely heavily on de-radicalization efforts to tackle terrorism. However, they mostly focus on the terrorists and lack attention to those around them, especially children. Meanwhile, in several cases of international terrorism, children have been actively involved in the acts (Gayatri, et al, 2019: 80).

The terrorist movement has recently penetrated into the domestic area by involving children (including early childhood) to become suicide bombers, inculcating radical values in children is very massive in Kindergarten (Arie W, 2014: 70) . The suicide bombing in Surabaya, 2018, shows that children are no longer safe from the violence and terrorists due to the ambition and wrong understanding of parents. What happened in Surabaya did not rule out the possibility that it would take place in other areas (including in Bima). Moreover, Bima is already well-known for several radical and terrorist acts from several groups.

The incidence occurred in Surabaya and several cases of violence and terrorism that occurred in Bima so far have been well aware of by the government and Bima society so that they are aware of the danger to their generation. According to the Bima religious leader, HMS (interview, December 2018), because radicalization has involved children, de-radicalism 
Asyari, A., \& Kadri (2020). COUNTER-RADICALIZATION IN EARLY CHILDHOOD THROUGH EFFECTIVE COMMUNICATION BETWEEN EDUCATION STAKEHOLDERS IN BIMA. Jurnal Tatsqif, 18 (1), 1-21. https://doi.org/10.20414/itq.v17i2.2262

efforts must target early childhood. Therefore, this is the role of families and schools to instill universal truth values from an early childhood without having to mortgage basic religious beliefs. By getting used to mingling each other between religions, forging cooperation in social and humanitarian affairs, and avoiding exclusive forms in society need to be instilled from an early childhood so that the positive exposure will enter their brains.

The HMS, as a community leader in Bima, hopes that have not been fully implemented optimally. Non-formal education institutions at the early childhood level have not fully devoted themselves to teaching counterradicalization content. When the researcher asked two non-formal early childhoods education institutions in Bima about the curriculum and learning media or educational teaching aids they were using, it turned out that they did not have a specific curriculum on counter-radicalization. The teaching aids used also do not show a pluralistic nuance. For example, the props for places of worship that are owned are mosques, even though other religious places of worship also need to be introduced to the students.

It is ironic if early childhood education institutions managed by the Education Office (not under the Ministry of Religion) such as early childhood education programs in the Pena Toi village area do not teach inclusive values and diversity to their students. Moreover, the Pena Toi area has been known as the base for radical groups, which in this region have prepared an inclusive education pattern with content that is full of counter-radicalization values to build a tolerant future generation.

The condition of early childhood education in Bima regency area is also similar to that in Bima city area. In early childhood and kindergarten located around Ambalawi district, for example, character education is not found in materials related to counter-radicalization, even though these areas are often used by radical and terrorist groups to carry out physical training and educate new members. In 2017, two terrorist carriages from the city of Bima were shot dead at this place. 
Asyari, A., \& Kadri (2020). COUNTER-RADICALIZATION IN EARLY CHILDHOOD THROUGH EFFECTIVE COMMUNICATION BETWEEN EDUCATION STAKEHOLDERS IN BIMA. Jurnal Tatsqif, 18 (1), 1-21. https://doi.org/10.20414/itq.v17i2.2262

The expectation of the Bima people for the government is very high to encourage the application of the counter-radicalization curriculum. According to the Bima community leader, HAA (interview, January 2019), the deradicalization that has been carried out by the government may need to be supplemented with approaches to early childhood education institutions. Therefore, he hopes that there will be a role for related agencies to formulate a policy and curriculum that can be applied to minimize, even to eliminate the potential for radical exposure at the early education level. According to him, if a child is exposed like this from an early age, it will become a permanent memory in his brain, so that later when the child grows up, he will have a strong understanding of the truth, and it is not easy to mislead other people who have different views on several matters.

One of the strategies that can be taken to prevent acts of terrorism in Bima is through reforming the curriculum, especially in early childhood education institutions. In terms of "material", what can be done is to present material on anti-terrorism or counter-radicalization education according to the level of the study unit. The material must be conveyed properly based on reliable sources and based on facts that are currently occurring in the community. The delivery of material must be easily understood by students.

The strategy above can be a good solution amid the lack of government concepts in dealing with this. It must be admitted that from a "concept" perspective, the government has not thought maximally about solving the problem of terrorism from its roots and has not taken any preventive action as a solution to eradication acts of terrorism that have defamed the region and the nation. Therefore, one of the recommendations of this study is to provide ideas by conducting a research to provide anti-terrorism or counterradicalization education from an early age, which has not been done so far. This step can be a solution to save the nation's generation from acts of terrorism. 
Asyari, A., \& Kadri (2020). COUNTER-RADICALIZATION IN EARLY CHILDHOOD THROUGH EFFECTIVE COMMUNICATION BETWEEN EDUCATION STAKEHOLDERS IN BIMA. Jurnal Tatsqif, 18 (1), 1-21. https://doi.org/10.20414/itq.v17i2.2262

Educational institutions at the early age level must be encouraged to teach the values of counter-radicalization comprehensively as an effort to tackle the growth and development of radicalism among children. This is what according to this research is known as a cultural way to fight acts of terror and violence committed by radical groups. Deradicalisation and counter-radicalization as a way to fight radical ideologies and groups are termed by Kadri (2016) as an effort to fight terrorists and radicals without weapons, especially by promoting softer approaches such as building good social communication and making family communication effective in each household.

The counter-radicalization agenda is an early way to fight radicalism. Therefore, the radicalism that has developed in Bima must not only be resisted repressively when they commit acts of violence but must also be confronted or stopped by its spread by counter-movement or what is commonly known as the counter-radicalization and deradicalisation movement, which is a necessity (Zuhdi, 2015: 28) and enlightening solutions to tackle the terrorist threat. Using religious approach is a form of deradicalisation which is considered effective rather than using weapons and bullets which will actually create revenge and wider acts of terror.

This study found that there is a lack of counter-radicalization agenda efforts undertaken by educational institutions at the early childhood level. They do not show concern for the future of their children who live and interact with a radical environment. On the other hand, educational institutions are important institutions that can be maximally utilized to build a line of resistance against radicalism. Utilizing educational institutions can be done through changing the curriculum as proposed by Saifuddin (2016) with the Problem Based Learning approach.

As a base for the development of radical groups, Bima ideally should provide protection for children from the influence of radical schools that have recently started to be develop in Bima region. The government and the 
Asyari, A., \& Kadri (2020). COUNTER-RADICALIZATION IN EARLY CHILDHOOD THROUGH EFFECTIVE COMMUNICATION BETWEEN EDUCATION STAKEHOLDERS IN BIMA. Jurnal Tatsqif, 18 (1), 1-21. https://doi.org/10.20414/itq.v17i2.2262

society in Bima may choose the type of preventive deradicalization (Rokhmad, 2012) to be applied in early childhood. This type of deradicalization is considered appropriate because children are a vulnerable group to various ideologies. Therefore, the act of deradicalization to them (early childhood) is an effort to develop their immunity and to protect them from radical ideologies that potentially destroy their future.

According to Munir (in Detiknews, 15 May 2018), early childhood is very vulnerable to any influences because neurons are formed from in the womb to a maximum of 2 years of age. The formation of the human brain in humans develops rapidly from birth to adolescence. This is because there is a process of forming a relationship between one neuron cells and thousands of other neuron cells which is called synaptogenesis. Thus, whatever inputs coming to their brains will form the nature and style of the synapse (junction cells), which ultimately shape the function and anatomy of the synapse (plasticity).

\section{Structural and Cultural Policies that Do not Support Agenda of Counter Radicalization}

Radicalism and acts of terrorism in Bima should not be taken for granted. Several acts of violence and terrorism in Bima are related to the spread of radicalism in the area. Therefore, concrete and systematic steps are needed to counter radicalization through children's education, especially through cultural and structural approach.

Structurally or politically, affirmative policies have not been found in preventing the dangers of terrorism and radicalism in Bima. In terms of regulations, take for example in Bima district, rules or regulations dealing with counter agenda of terrorism and radicalism are not found, specifically regulation on the prevention of terrorism and radicalism from an early age. Therefore, it is not surprising if people expect counter-radicalization efforts from the government and house representative (DPRD) to provide a strong legal umbrella dealing with terrorists by making related regional regulations. 
Asyari, A., \& Kadri (2020). COUNTER-RADICALIZATION IN EARLY CHILDHOOD THROUGH EFFECTIVE COMMUNICATION BETWEEN EDUCATION STAKEHOLDERS IN BIMA. Jurnal Tatsqif, 18 (1), 1-21. https://doi.org/10.20414/itq.v17i2.2262

The initiatives should be taken as soon as possible, otherwise it might provide time and opportunity for terrorists to consolidate and to prepare, even it is possible for them to influence the children and other young generations whose minds are innocent with the teachings of violence and radicalism.

In the context of the budget, it must be admitted that Bima district government and Bima city government have not maximally allocated funds for countering radicalism and terrorism. One of the reasons for local governments is that they do not have too much authority to handle this matter. The head of the Kesbangpoldagri Bima district, H. Ishaka (interview, August 2018) admitted that the regional government has not maximally allocated the regional budget for this because the authority on radicalism and terrorism is mostly at the central government.

The partial support for counter-radicalization program budgets as an effort to combat radicalism and acts of violence and extremism by local governments shows that government has low political will in planning a budget for counter-radicalization education. It might result in a lack of solutions to problems of violence and extremism in the regions. The correlation between budgeting commitment and the form of a program like this is quite valid because according to Mardiasmo (2009) a budget is a managerial plan for action to facilitate the achievement of organizational goals. Therefore, it is deemed important for local governments to prepare an appropriate and maximum budget for tackling the dangers of terrorism, through anti-terrorism education from an early age. This is one of the effective steps that can succeed the idea toward free-terrorism zone in the province of West Nusa Tenggara.

Similar to the structural efforts through the government, counterradicalization efforts through cultural approach also did not work well. The community looks normal without any worries with the various radical actions and terrorism that have occurred in Bima. Bima community did not 
Asyari, A., \& Kadri (2020). COUNTER-RADICALIZATION IN EARLY CHILDHOOD THROUGH EFFECTIVE COMMUNICATION BETWEEN EDUCATION STAKEHOLDERS IN BIMA. Jurnal Tatsqif, 18 (1), 1-21. https://doi.org/10.20414/itq.v17i2.2262

anticipate this by preparing or educating their children from an early age with inclusive values.

Of course, the people and the government in Bima do not want the future of the children in their area to be dark because they fall into radical and terrorist groups. They do not want their children to be exploited by groups adhering to violence and terrorism, especially the Islamic State of Iraq and Syria (ISIS), including victims of propaganda in cyberspace. Even from some of the propaganda videos, ISIS has targeted Indonesian children to be recruited into their network.

This condition is very sad because children are still innocent and should not be held hostage in spreading the understanding of violence and terrorism. This condition requires the Indonesian government in general and the district government of Bima and Bima city in particular to provide protection for children from the spread of this understanding. One way to strengthen early childhood education is by injecting them with the values of nationalism and anti-violence. This method is what the National Counterterrorism Agency (BNPT) calls a counter-radicalization strategy, namely an effort to instill Indonesian values and non-violent values, which among others are carried out through cultural channels such as family education, community education and formal institutions.

\section{Less Communicative and Collaborative Counter-Radicalization Education} Stakeholders

Although parents and educators as well as the government are both aware that acts of violence and radicalism by youths from radical groups are not good for the region and Bima generation, this research did not find any serious efforts among these parties to take communicative and collaborative steps in overcoming this through preventive action. Each party carries out its duties according to the habit as it is without considering or including specially-prepared counter-radicalization content. 
Asyari, A., \& Kadri (2020). COUNTER-RADICALIZATION IN EARLY CHILDHOOD THROUGH EFFECTIVE COMMUNICATION BETWEEN EDUCATION STAKEHOLDERS IN BIMA. Jurnal Tatsqif, 18 (1), 1-21. https://doi.org/10.20414/itq.v17i2.2262

The absence of communication and coordination in counterradicalization education in Bima is reflected in the following statements by three informants with different professions. One of the PAUD educators in Kota Bima, IDD said that during his teaching, he never specifically conveyed counter-radicalization material to children. Instead he loved to share values of loving the homeland (nationalism) in some occasions. According to IDD, there are no specific instructions from the local government regarding counter-radicalization content (interview with IDD, September 2018). AlW, an official at the Bima City Education Office also admitted that his office had never had a special program to strengthen the counter-radicalization agenda in early childhood, including no oral or written instructions related to this in early childhood education institutions (interview with ALW, October 2018). Parents who live not far from Penatoi village also said that they did not have excessive concern that the existence of radical groups would affect the growth of their young children (interview with SHR, October 2018).

The absence of coordination and communication between educational stakeholders in instilling the value of counter-radicalization in early childhood in Bima mislead the direction of fostering the Islamic character of future generations. This fact also makes Bima like an open field where all religious understandings fight to spread the influence. Efforts to educate character and counter-radicalization values that are not explicitly implemented and coordinated show that each stakeholder is not serious about protecting children from the influence of radical groups. This is also exacerbated by the lack of massive shared religious agendas carried out by parents (the community) with educational institutions and the government. If this still continues, it is feared that early childhood will be led to center of massive radical group activities through da'wah activities and exclusive educational institutions that they organize. It is in this context that the counter-radicalization agenda becomes bleak, and the future of the generation in Bima is predicted to be influenced by radical ideas that are 
Asyari, A., \& Kadri (2020). COUNTER-RADICALIZATION IN EARLY CHILDHOOD THROUGH EFFECTIVE COMMUNICATION BETWEEN EDUCATION STAKEHOLDERS IN BIMA. Jurnal Tatsqif, 18 (1), 1-21. https://doi.org/10.20414/itq.v17i2.2262

contrary to the values of inclusiveness that should characterize every generation of Islam.

Ideally, Bima, which has a high level of violence and radicalism from other regions in NTB, requires intense coordination and communication between stakeholders, which can be realized in the form of a joint program for counter-radicalization education in early childhood. Every stakeholder actually makes the counter-radicalization agenda as a common concern that shows commitment to realize an inclusive and peace-loving generation of Bima Muslims or non-violent generation. With the same commitment and attention, their communication will be effective. The similarity of commitment in relation to the effectiveness of such communication can be illustrated in the model in Figure 2.

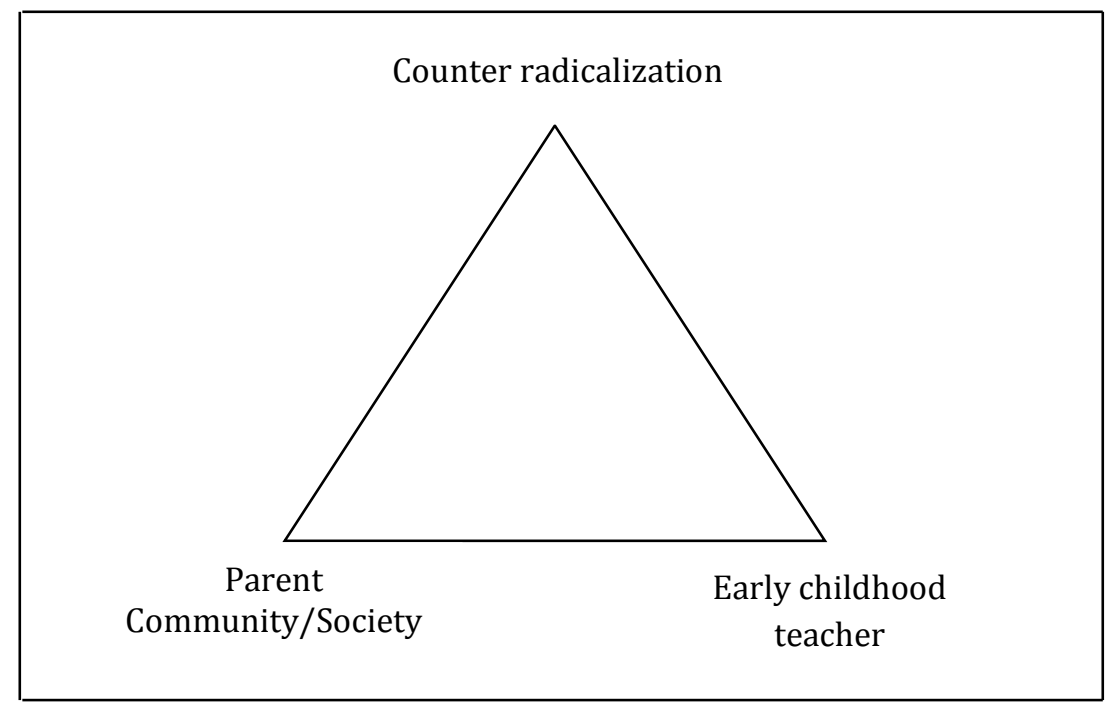

Figure 2: Effective communication model in counter-radicalization

Effective communication model in counter-radicalization agenda as seen in figure 1 is a modified model of the ABX Newcomb Model (Mulyana, 2018: 143), which means that efforts to instill counter-radicalization values in early childhood can work well if there is equal communication between all 
Asyari, A., \& Kadri (2020). COUNTER-RADICALIZATION IN EARLY CHILDHOOD THROUGH EFFECTIVE COMMUNICATION BETWEEN EDUCATION STAKEHOLDERS IN BIMA. Jurnal Tatsqif, 18 (1), 1-21. https://doi.org/10.20414/itq.v17i2.2262

stakeholders (parents, community, PAUD educators, and government) form the same commitment to make counter-radicalization as a common agenda. The similarity in orientation and commitment to counter-radicalization in the model is indicated by the symmetrical angle of the triangle from each stakeholder leading to the vertex of the corner, which is the angle of deradicalization.

Collaborating in instilling counter-radicalization values in early childhood is the right choice because it can guarantee the continuity of educational content that must be received by children. For example, if the counter-radicalization education is given at home, the content will be more steadily accepted by the children if the same content (counter-radicalization) is also implanted when the child is in an early childhood education institution. Therefore, collaboration between parents and educators is a good choice in building children's character towards a better direction (such as counter-radicalization). Relevant to this assumption, Supriyanto's study (2016) shows that collaboration between parents as primary education with teachers and counselors as second parents is considered effective in developing competency in early childhood comprehensively through consulting services.

If parents, communities, educators, and local governments in Bima do not carry out early counter-radicalization efforts on children, then they can be considered to provide space for radical groups to influence children. Moreover, the phenomenon of exploiting children into radical group networks recently has become a national and international concern. Advianti (detik.com, 3 June 2016) said that children who have been victims of radicalism indoctrination need rehabilitation to correct the ideological values of terrorism that they have absorbed during the incubation period. 
Asyari, A., \& Kadri (2020). COUNTER-RADICALIZATION IN EARLY CHILDHOOD THROUGH EFFECTIVE COMMUNICATION BETWEEN EDUCATION STAKEHOLDERS IN BIMA. Jurnal Tatsqif, 18 (1), 1-21. https://doi.org/10.20414/itq.v17i2.2262

\section{CONCLUSION}

Early childhood education in Bima has not made the issue of radicalism and terrorism as a threat to future generations. Hence, they do not explicitly make counter-radicalization content included in the early childhood education curriculum. The educational materials and teaching media used are still exclusive and do not reflect inclusive knowledge regarding the diversity that exists in Indonesia, even though early childhood is the right time to instill the values of inclusiveness towards tolerant and non-violent generation.

The counter-radicalization agenda has not become a routine and massive agenda in the context of structural or government policies or in the cultural paths carried out by the community and educators in educational institutions. There are no regulations explicitly related to the counterradicalization agenda and there is still minimal alignment with the related budget. The society also does not seem worried about the growth of radical groups in their region and acts of violence by terrorist groups. Therefore, the community does not have a special counter-radicalization program as a preventive step in preventing their children from being influenced by radicalism.

Communication between education stakeholders in Bima in initiating and implementing the counter-radicalization agenda has not been effective, even though they are aware that Bima known as area prone to radicalism. Education stakeholders in Bima have not made the counter-radicalization agenda as common concern and attention, while effective communication related to overcoming the dangers of radicalism occur when all education stakeholders such as parents, educators, the community, and the government have the same attention to counter radicalization as their communication content. . Therefore, effective communication from education stakeholders in counter-radicalization programs in early childhood must be realized to ensure the presence of an inclusive and non-violent Bima generation. 
Asyari, A., \& Kadri (2020). COUNTER-RADICALIZATION IN EARLY CHILDHOOD THROUGH EFFECTIVE COMMUNICATION BETWEEN EDUCATION STAKEHOLDERS IN BIMA. Jurnal Tatsqif, 18 (1), 1-21. https://doi.org/10.20414/jtq.v17i2.2262

\section{REFERENCES}

Echol, J. M., \& Shadily, H. (1995). Kamus Inggris Indonesia. Jakarta: Gramedia.

Effendy, O. U. (2017). Ilmu, Teori dan Filsafat Komunikasi. Bandung: Citra Aditya Bakti.

Gayatri, E., \& Kosasih, K. (2019). "Break the Chain of Terrorism Through Deradicalization of (Former) Terrorists'children: Narration from AlHidayah Pesantren, Medan." Analisa: Journal of Social Science and Religion 4 (1).

Hilmi, M. (2015). “Anak Muda di Tengah Pusaran Radikalisme”, Opinion. http://digilib.uinsby.ac.id/14245/

https://regional.kompas.com/read/2018/05/13/17403531/pelaku-bom-

bunuh-diri-di-surabaya-diduga-berasal-dari-satu-keluarga, accessed March 22, 2020

https://www.jawapos.com/nasional/hukum-kriminal/30/10/2017/bakutembak-di-bima-dua-terduga-teroris-tewas/, accessed February 20, 2020

Huberman, A. M. \& Matthew, M. B. (1992). Analisis Data Kualitatif. Translate by Rohendi Rohidi. Jakarta: UI Press.

Kadri. (2016). "Melawan Teroris Tanpa Peluru”. Harian Lombok Post News, January 9, 2016.

Kruglanski, A. W. et al. (2014). "The psychology of radicalization and deradicalization: How significance quest impacts violent extremism." Political Psychology 35.

Mardiasmo. (2009). Akuntansi Sektor Publik. Yogyakarta: ANDI.

Milla, M. N. et al. (2020). "Attitude toward rehabilitation as a key predictor for adopting alternative identities in deradicalization programs: An investigation of terrorist detainees' profiles." Asian Journal of Social Psychology 23 (1).

Moleong, L. J. (2000). Metodologi Penelitian Kualitatif. Bandung: Remaja Rosdakarya. 
Asyari, A., \& Kadri (2020). COUNTER-RADICALIZATION IN EARLY CHILDHOOD THROUGH EFFECTIVE COMMUNICATION BETWEEN EDUCATION STAKEHOLDERS IN BIMA. Jurnal Tatsqif, 18 (1), 1-21. https://doi.org/10.20414/itq.v17i2.2262

Nusatenggara Centre. (2017) Tindak Kekerasan dan Ekstremisme di NTB: Identifikasi Fakta, Ancaman, dan Modal Sosial. Research Report (Unpublish).

Rokhmad, A. (2012). "Radikalisme Islam Dan Upaya Deradikalisasi Paham Radikal". Jurnal Walisongo 20 (1).

Rosili, N. A. K. (2016). “De-Radicalization Programs In South-East Asia: A Comparative Study Of Rehabilitation Programs In Malaysia, Thailand, Indonesia \& Singapore." Journal of Education and Social Sciences 4 (June).

Saifuddin. (2016). "Redesain Pendidikan Agama Islam Dengan Strategi Problem Based Learning untuk Meningkatkan Kemampuan Berpikir Kritis (Sebuah Upaya Mereduksi Terorisme dan Radikalisme Agama)", Jurnal Ilmiah Vicratina 10 (2) Nopember.

Santoso, E. \& Setiansah, M. (2010). Teori Komunikasi. Yogyakarta: Graha Ilmu Sukabdi, Z. (2015). "Terrorism in Indonesia: A review on rehabilitation and deradicalization." Contemporary Voices: St Andrews Journal of International Relations 6 (2).

Supriyanto, A. (2016). "Kolaborasi Konselor, Guru, dan Orang Tua untuk Mengembangkan Kompetensi Anak Usia Dini Melalui Bimbingan Komprehensif", Jurnal Care (Children Advisory Research And Education) 4 (1).

Williams, R. (2007). "The psychosocial consequences for children of mass violence, terrorism and disasters." International Review of Psychiatry 19 (3).

Zuhdi, M. H. (2015). Deradikalisasi Agama. Mataram: Sanabil. 